\title{
Pendampingan Pemanfaatan Media Sosial Dan E-Commerce Sebagai Peluang Usaha Mandiri pada Masa Pandemi Covid-19 di Desa Pandansari Kecamatan Poncokusumo Malang
}

\author{
Imamatus Sholihah') \\ 1)IAI Sunan Kalijogo Malang \\ 1) Imamatussh10@gmail.com
}

\begin{abstract}
Abstrak. Covid-19 telah memberikan dampak negatif pada tiga bidang kehidupan yaitu kesehatan, pendidikan, dan ekonomi. Banyak pelaku bisnis yang gulung tikar, tidak memenuhi target usahanya, dan daya beli masyarakat menurun. Selain itu, masa pandemic sebenarnya memberikan peluang untuk usaha mandiri dengan memanfaatkan Media Sosial dan e-commerce. Dengan kemajuan teknologi saat ini dapat memanfaatkan peranan internet dan perangkat mobile yang dimiliki untuk mengembangkan usaha yang dimiliki secara online sehingga memungkinkan pencapaian pasar yang lebih luas. Hal ini memberikan semangat peneliti untuk memberikan pendampingan terhadap beberapa penjual atau seller dengan berjualan online melalui sosial media maupun beberapa platform seperti Tokopedia, Bukalapak, dan Shopee di desa Pandansari Kecamatan Poncokusumo Malang. Tujuan penelitian ini adalah memberikan informasi kepada masyarakat untuk memanfaatkan digital sebagai toko online shop dengan mengoptimalkan dan menciptakan perekonomian lokal yang lebih baik dan lebih kuat dari sebelumnya. Dalam penelitian ini menggunakan pendekatan kualitatif deskriptif, dengan metode pengumpulan data menggunakan observasi, sedangkan obyek penelitiannya adalah masyarakat di desa Pandansari Kecamatan Poncokusumo Malang. Hasil dari analisis penelitian ini ialah adanya pandemic ini, banyak kehilangan pekerjaan yang secara tidak langsung memacu masyarakat untuk menggali kemampuan dan skill diri, sehingga mendorong mereka untuk menciptakan usaha secara online dengan memanfaatkan digital sebagai toko online shop mulai lewat sosial media maupun beberapa platform seperti Tokopedia, Bukalapak, dan Shopee.
\end{abstract}

\section{Kata Kunci: Media Sosial; Usaha Mandiri; Masa Pandemi Covid-19}

\begin{abstract}
Covid-19 has had a negative impact on three areas of life, namely health, education and the economy. Many business people have gone out of business, have not met their business targets, and people's purchasing power has decreased. In addition, the pandemic period actually provides opportunities for independent businesses by utilizing social media and e-commerce. With current technological advances, you can take advantage of the role of the internet and mobile devices you have to develop your business online so as to enable the achievement of a wider market. This gives the spirit of researchers to provide assistance to several sellers or sellers by selling online through social media and several platforms such as Tokopedia, Bukalapak, and Shopee in Pandansari village, Poncokusumo District, Malang. The purpose of this research is to provide information to the public to use digital as an online shop by optimizing and creating a better and stronger local economy than before. In this study using a descriptive qualitative approach, with the method of collecting data using observation, while the object of research is the community in Pandansari Village, Poncokusumo District, Malang. The result of this research analysis is that there is this pandemic, many job losses have indirectly spurred people to explore their abilities and skills, thus
\end{abstract}


encouraging them to create online businesses by utilizing digital as an online shop, starting through social media and several platforms such as Tokopedia , Bukalapak, and Shopee.

Keywords: Social Media; Independent Business; Covid-19 Pandemic Period.

\section{PENDAHULUAN}

Permulaan tahun 2020 hingga pertengahan tahun ini merupakan tahun yang berat bagi seluruh negara bagian di dunia, karena muncul sebuah virus baru yakni virus Corona atau sering disebut dengan Covid-19. Virus ini menjadi sebuah wabah yang sangat berpengaruh besar pada kehidupan. Virus corona (covid-19) merupakan virus yang menyerang pernafasan manusia hingga menyebabkan kematian. Virus ini pertama kali muncul di Wuhan China. Hal ini sangat membuat masyarakat resah. Sejak Covid-19 ini masuk ke Indonesia, banyak kebijakan yang ditetapkan oleh pemerintah. Kebijakan tersebut antara lain penetapan PSBB, penggunaan masker, rajin mencuci tangan dan menjaga jarak ditempat keramaian. Munculnya wabah ini menyebabkan perekonomian menjadi lesu. Adanya himbauan agar masyarakat stay at home menyebabkan sebagaian orang menjadi memilih untuk beraktivitas dirumah. Hal ini mengakibatkan sebagian besar pendapat masyarakat menurun, tingkat konsumsi menurun bahkan banyak terjadi PHK. ${ }^{1}$

Covid-19 merupakan virus yang sejenis dengan virus pneumonia yang sudah sering kita dengar. Virus corona menginfeksi paru-paru sehingga mereka yang terjangkit virus ini akan mengalami gangguan akut pada saluran pernafasan. Jika Pneumonia bisa dengan mudah disembuhkan beda halnya dengan Covid-19 ini, bila terjangkit penderita akan mengalami kerusakan saluran pernafasan dan yang paling parah covid-19 menyebabkan kematian dan sampai saat ini korban meninggal dunia dikabarkan sudah mencapai jutaan jiwa. Berbagai upaya dilakukan guna mencegah masuknya virus Covid-19 Ke Indonesia, namun tidak semudah itu bisa terhindar dari penyebaran Covid-19.

Kasus Covid-19 di Indonesia terus meningkat, tercatat per 1 September 2020 sebanyak 177.571 orang positif covid-19, 12.057 orang sembuh, dan 7.505 orang meninggal dunia dan angka ini bisa saja akan terus bertambah. Angka masyarakat yang positive covid19 terus meningkat, padahal pemerintah dan tim medis sendiri sudah melakukan cara terbaik sesuai dengan kemampuan dan kondisi Indonesia saat ini. Peningkatan jumlah kasus positif covid-19 ini akan menyebabkan kepanikan di tengah masyarakat dan kecemasan

${ }^{1}$ Laily Muzdalifah dkk, Pemberdayaan Pelaku UMKM Menuju UMKM Go-Digital Di Era Pandemi Covid 19 Dan Era New Normal Bagi Pelaku UMKM Sidoarjo, (Malang: UNMER, 2020), 2201. 
masyarakat terutama dalam memenuhi kebutuhannya. Belum lagi banyak dari masyarakat yang di rumahkan serta di PHK dan tidak ada pilihan demi bisa bertahan hidup mereka menggunakan tabungan untuk memenuhi kebutuhan mereka sementara. Hal ini jika terus berlanjut justru akan menambah beban bagi pemerintah, karena jika tabungan individu itu habis, maka pemerintah harus memberikan bantuan langsung tunai supaya masyarakat tidak semakin melarat selama menghadapi pandemik ini.

Covid-19 tersebut berdampak pada tiga bidang kehidupan yaitu kesehatan, pendidikan, dan ekonomi. Banyak pelaku bisnis yang gulung tikar, tidak memenuhi target usahanya, dan daya beli masyarakat menurun. Sebenarnya Indonesia telah merajai sektor ECommerce di ASEAN untuk pertama kalinya. Kondisi ini harus dimaknai dengan dua sikap yaitu hal ini merupakan prestasi bagi masyarakat Indonesia dan menjadi tantangan bagi Pemerintah agar terus mengembangkan sektor e-commerce. Ada beberapa faktor yang mendukung pertumbuhan pesat sektor E-commerce di Indonesia. Pertama, penetrasi smartphone dan internet terus meningkat. Kedua, jumlah penduduk Indonesia yang besar dan daya belinya meningkat di tengah pertumbuhan makroekonomi yang kuat. Ketiga, Indonesia memiliki populasi yang muda dan faham teknologi, artinya mereka dengan cepat menyesuaikan diri dengan teknologi baru. Selain itu, sekarang dunia sedang dilanda pandemi Covid-19, yang berdampak salah satunya terhadap pemenuhan kebutuhan. Hal ini menyebabkan respon positif masyarakat yang beralih ke transaksi jual beli melalui $e$ commerce. Di Indonesia sendiri E-commerce sudah ada sejak tahun 2000-an. Namun, pada tahun 2014 penggunaan E-commerce baru marak diminati masyarakat. Dibuktikan dengan banyaknya perusahan start-up di Indonesia, seperti Tokopedia, Bukalapak, Blibli, Shopee, dan masih banyak lagi. Perkembangan E-commerce yang begitu pesat dipengaruh oleh beberapa faktor yang menyebabkan individu untuk berbelanja online di situs E-commerce diantaranya, biaya murah, kualitas barang, kepercayaan, fasilitas transaksi yang beragam, dan masih banyak faktor lainnya yang didasarkan pada kebutuhan individu yang beragam pula. ${ }^{2}$

Ditinjau dari sisi kebutuhan harian, saat ini individu memenuhi kebutuhan bukan hanya sekadar mencukupi kebutuhan sandang, pangan, dan papan. Namun, juga mengutamakan pelayanan, kualitas dan harga dari suatu produk atau jasa penjualan. Hal ini menjadi peluang bagi sebagian besar perusahaan E-commerce untuk menyajikan pasar dalam bentuk membeli dan menjual produk secara online. E-commerce mencakupi segala proses

2 Alvin Edgar dkk, Analisa Transaksi Belanja Online Pada Masa Pandemi Covid-19, Surabaya: Institut Tekonologi, Jurnal TEKNOINFO, Vol. 15, 2021, jurnal diakses pada tanggal 30 Juni 2021, 32. 
pengembangan, pemasaran, penjualan, pengiriman, pelayanan, dan pembayaran para pelanggan, dengan dukungan dari jaringan mitra bisnis yang lebih luas. Sistem yang digunakan dalam penggunaan E-commerce sangat mengandalkan internet dengan jumlah pengguna yang sangat potensial dengan peningkatan dari tahun ke tahun. Internet merupakan kebutuhan pokok di era mileneal seperti sekarang ini. Internet memudahkan segala aspek kehidupan mulai dari pendidikan hiburan, informasi, pelayan publik, pengetahuan, iklan, investasi, interaksi atau komunikasi, serta bisnis dan berjualan. Adanya internet inilah diharapkan menjadi instrumen pendukung dan penguat para pelaku ekonomi kreatif dan UMKM dalam mengembangkan bisnis dan memasarkan jualannya. Kegiatan bisnis di Indonesia sebagian besar didominasi oleh masyarakat melalui bingkai Ekonomi Kreatif (selanjutnya disebut Ekraf) dan Usaha Mikro Kecil dan Menengan (selanjutnya disebut UMKM).

Pemberdayaan masyarakat melalui iptek digitalisasi UMKM Desa menjadi sangat penting dilakukan dalam era informasi sekarang ini. Dengan semakin banyaknya usaha kecil dan menengah yang terlibat dalam ekonomi digital melalui broadband, e-commerce, media sosial, cloud, dan mobile platforms. UKM dapat bertumbuh lebih cepat dari segi pendapatan dan penyediaan lapangan kerja, serta menjadi lebih inovatif dan lebih kompetitif untuk menghadapi Masyarakat Ekonomi ASEAN. Konsep Pengembangan Ekonomi Lokal (PEL) memberi penekanan pada pemanfaatan secara maksimal terhadap sumber daya, kapasitas dan keterampilan yang ada di daerah. PEL didefinisikan sebagai suatu kerjasama yang terjalin antara pemerintah, dunia usaha, serta sektor non pemerintah dan masyarakat untuk mengidentifikasi dan juga memanfaatkan sumber daya lokal yang dimiliki daerah guna mengoptimalkan dan menciptakan perekonomian lokal yang lebih baik dan lebih kuat dari sebelumnya. ${ }^{3}$

Pergerakan dan perubahan cara berbisnis yang kian cepat ke arah digitalisasi ini memaksa pelaku bisnis untuk beradaptasi mengikuti perubahan tersebut. Bagi perusahaan besar, perubahan pola bisnis yang mengarah pada proses digitalisasi ini tidak terlalu mengalami kendala ikarenakan dengan karakteristik perusahaan besar yang memiliki sumber daya yang cukup baik. Namun, bagi UMKM proses digitalisasi ini akan membutuhkan banyak persiapan. Permasalahan bagi Ekraf dan UMKM sangat banyak diantaranya kurangnya pengetahuan terhadap pendirian UMKM, tidak dimiliknya izin, masalah sengketa

3 Annysa Endriastuti dan Maurisia Putri, Pelatihan Pemasaran, Pemberdayaan Toko Online, dan Pengenalan M-Commerce pada Produk Unggulan Jagung Tortila Di Kecamatan Trucuk Kabupaten Bojonegoro, Universitas Airlangga, Jurnal Pengabdian Masyarakat, Vol. 1 No. 2 Tahun 2018, jurnal diakses pada tanggal 01 Juli 2021, 57-58. 
Hak atas Kekayaan Intelektual (HKI), dan juga masalah yang paling pokok adalah strategi pemasaran melalui digital. ${ }^{4}$ Saat ini peranan teknologi informasi berpengaruh dalam dunia ekonomi khususnya dalam hal penjualan. ${ }^{5}$

Pasca pandemi terdapat beberapa usaha yang melejit di tengah pandemi yaitu, penjuakan masker kain, hand sanitizer, kuliner dengan berbagai kuliner yang unik dan murah, serta jasa kurir yang menyediakan jasa pengiriman barang karena banyak masyarakat yang enggan bepergian dan lebih memilih menggunakan jasa kurir untuk mengirim barang. Menjamurnya usaha kuliner di tengah pandemik dengan jenis makanan yang beragam membuat masyarakat semakin dimanjakan yang menyebabkan keinginan untuk berbelanja lebih tinggi. Melihat perubahan ini membuat kita berfikir bahwa pandemic covid-19 memberi dampak yang sangat besar dan komplek. Banyak yang kehilangan pekerjaan yang secara tidak langsung memacu masyarakat untuk menggali kemampuan dan skill diri, sehingga mendorong mereka untuk menciptakan usaha kecil-kecilan yang secara tidak langsung dapat memenuhi kebutuhan hidup masyarakat lainnya dan secara tidak langsung membuat kaum perempuan menjadi lebih produktif.6 Sebenarnya banyak pelaku UMKM yang belum memahami bagaimana cara menyusun Laporan Keuangan kegiatan usahanya, sehingga membutuhkan informasi keuangan yang sebenarnya. ${ }^{7}$

Masa pandemic sebenarnya memberikan peluang untuk usaha mandiri dengan memanfaatkan Media Sosial Dan e-commerce. Dengan kemajuan teknologi saat ini dapat memanfaatkan peranan internet dan perangkat mobile yang dimiliki untuk mengembangkan usaha yang dimiliki secara online sehingga memungkinkan pencapaian pasar yang lebih luas. Hal ini memberikan semangat peneliti untuk memberikan pendampingan terhadap beberapa penjual atau seller dengan berjualan online melalui sosial media maupun beberapa platform seperti Tokopedia, Bukalapak, dan Shopee di desa Pandansari Kecamatan Poncokusumo Malang. Hasil observasi di desa pandansari dan penjelasan terkait produk jualan online akan peneliti paparkan pada poin selanjutnya.

4 Nizam Zakka dan Sofyantoro, Pemberdayaan Ekonomi Kreatif dan UMKM di Masa Pandemi Melalui Digitalisasi, Madiun: Universitas PGRI, Jurnal Pemerintahan, Pembangunan dan Inovasi Daerah, Vol.2 No.1 Juni 2020, jurnal diakses pada tanggal 01 Juli 2021, 40-41

5 Fata Nidaul dkk, Pemanfaatan Media Sosial dan Ecommerce Sebagai Media Pemasaran dalam Mendukung Peluang Usaha Mandiri Pada Masa Pandemi Covid 19, Junal JSTPM Vol. 1 No.1 Juli 2020, jurnal diakses pada tanggal 30 Juni 2021, 1-4.

6 Putu Novia dkk, Bisnis Kuliner Online, Solusi Usaha di Tengah Pandemi Covid-19, Denpasar: Universitas Mahasaraswati, Prosiding Webinar Nasional Peranan Perempuan/Ibu dalam Pemberdayaan Remaja di Masa Pandemi COVID-19, artikel diakses pada tanggal 01 Juli 2021, 123

7 Yananto Mihadi dkk, Pendampingan Penerapan Sistem Pemasaran Online dan Pelaporan Keuangan Sederhana Pada Sektor Usaha Kecil di Kelurahan Meruya Selatan, Jakarta: Universitas Mercu Buana, Jurnal Abdi Masyarakat, Vol.5 No.1 September 2019, jurnal diakses pada tanggal 01 Juli 2021, 28 


\section{METODE PELAKSANAAN KEGIATAN}

Penelitian ini menggunakan pendekatan kualitatif deskriptif. Dengan metode pengumpulan data menggunakan observasi. Sedangkan obyek penelitiannya adalah masyarakat di desa Pandansari Kecamatan Poncokusumo Malang.

\section{HASIL DAN PEMBAHASAN}

Pemerintah Indonesia melakukan upaya untuk melawan covid-19 dan berupaya untuk memotong rantai penyebaran covid-19. PSBB (pembatasan sosial skala besar), meniadakan segala aktivitas dan acara yang melibatkan banyak orang, penutupan sementara fasilitas-fasilitas umum yang ramai di kunjungi masyarakat, membatasi wisatawan aktivitas di bandara dan pelabuhan yang merupakan pintu keluar masuknya wisatawan domestik dan mancanegara, dan bahkan dibeberapa daerah menerapkan sistem lockdown. Pemerintah juga mengeluarkan instruksi untuk masyarakat membatasi aktivitas mereka di luar rumah. Masyarakat di himbau untuk melakukan segala aktivitas dari rumah, mulai dari bekerja, meeting, rapat, sekolah, dan aktivitas lainnya di lakukan dari rumah secara online.

Masa pandemic, membuat produsen akan berproduksi pada kondisi yang imperfect competition market sehingga mengakibatkan harga yang ditawarkan akan lebih besar dari marginal cost nya, dan produsen akan melakukan markup terhadap harga barang yang ditawarkan. Online shopping dan bisnis online saat ini bukan lagi menjadi sesuatu yang asing bagi masyarakat Indonesia. Adapun definisi online shop adalah suatu proses pembelian barang atau jasa dari mereka yang menjual barang atau jasa melalui internet dimana antara penjual dan pembeli tidak pernah bertemu atau melakukan kontak secara fisik yang dimana barang yang diperjualbelikan ditawarkan melalui display dengan gambar yang ada di suatu website atau toko maya. Setelah pembeli dapat memilih barang yang diinginkan, kemudian melakukan pembayaran kepada penjual melalui rekening bank yang bersangkutan. Setelah proses pembayaran di terima, kewajiban penjual adalah mengirim barang pesanan pembeli ke alamat tujuan.

Transaksi perdagangan secara konvensional telah beralih ke sistem online. Sistem perdagangan ini pada dasarnya sama dengan perjanjian jual beli pada umumnya, hanya saja penjual dan pembeli tidak perlu bertemu muka. Hal baru yang muncul dengan adanya perkembangan internet dan perubahan perilaku masyarakat adalah perdagangan elektronik (e-commerce). Perdagangan elektronik yang disebut juga e-commerce, adalah penggunaan 
jaringan komunikasi dan komputer untuk melaksanakan proses bisnis. ${ }^{8}$ Jenis transaksi jual beli yang menggunakan media internet dalam penjualannya saat ini yang paling banyak dilakukan adalah berbasis media sosial seperti, facebook, Instagram dan media sosial lainnya untuk memasarkan produk yang mereka jual. Saat ini penjualan on line merupakan salah atu bentuk jenis transaksi yang banyak dipergunakan dalam jual beli. Kemudian bagaimanakah perspektif ekonomi Islam dalam memandang penjualan on-line yang saat ini sudah menjadi suatu hal sudah sangat lumrah yang dilakukan dalam transaksi jual beli, terutama kepada penjualan on-line yang berbasis media sosial. ${ }^{9}$ Menurut Abdul Manap cara mengelola toko online dengan baik yaitu:

a. Pilihlah nama yang menarik.

b. Pilihlah produk yang tidak menyulitkan dalam proses pengiriman.

c. Aktiflah memberikan tips-tips penggunaan produk yang kita jual.

d. Berikan informasi mengenai penjualan user langsung atau membuka peluang reseller.

e. Gunakan testimony dari pelanggan

f. Jangan terlalu men-TCG friendship. ${ }^{10}$

Berdasarkan data digital 2020 menunjukkan 8 dari 10 pengguna internet membeli produk atau jasa secara online dengan menggunakan perangkat mobile. Berdasarkan data menunjukkan bahwa 93\% pengguna sudah mengetahui caranya bagaimana mencari informasi tentang suatu produk melalui internet kemudian melakukan kegiatan transaksi jual beli secara online. ${ }^{11}$ Minat masyarakat dalam berbelanja online memang lebih besar dibandingkan berbelanja secara langsung ke toko atau swalayan. Selain berbelanja lebih mudah dan simple, berbelanja online memberikan banyak pilihan, dalam sekali klik kita bisa menemukan berbagai macam pilihan produk dengan harga yang beragam, dan kita bisa memilih harga termurah dari produk yang ingin kita beli, melakukan pembayaran via online dan tinggal menunggu barang diantar ke alamat masing-masing. Bisnis online semakin di gandrungi dan semakin tinggi peminatnya di saat pandemik seperti saat ini. Banyak masyarakat yang beralih ke bisnis online. Beberapa keuntungan yang di rasakan memilih

8 Richardy Affan dkk, Analisis Transaksi Jual-Beli Online (Peer To Peer)Pada E-Commerce Berdasarkan Hukum Syariah, Journal Of Islamic Economics Lariba (2017). Vol. 3, Universitas Islam Negeri Syarif Hidayatullah, 31.

9 Nur Rianto Al Arif, Penjualan On-Line Berbasis Media Social Dalam Perspektif Ekonomi Islam, Jurnal Wacana Hukum Islam dan Kemanusiaan, 2013. Volume 23, No.1, jurnal diakses pada tanggal 02 Juli 2021, 39

10 Muzdalifah, Laily dkk, Pemberdayaan Pelaku Umkm Menuju Umkm Go-Digital Di Era Pandemi Covid 19 Dan Era New Normal Bagi Pelaku Umkm Sidoarjo.

11 Fata Nidaul dkk, Pemanfaatan Media Sosial dan Ecommerce Sebagai Media Pemasaran dalam Mendukung Peluang Usaha Mandiri Pada Masa Pandemi Covid 19. 
bisnis online di saat pandemi yaitu, menghindari kontak langsung dengan orang lain, menghindari resiko penularan melalui barang, mudah menemukan barang yang diinginkan, pembayaran dapat di lakukan secara online tanpa harus kontak langsung dengan penjual dan promo berupa potongan harga yang membuat kita berbelanja lebih hemat. Hal ini memberikan manfaat dan keuntungan yang menyebakan banyak pelaku usaha beralih ke ecommerce. E-commerce adalah suatu proses menjual atau membeli produk-produk secara elektronik oleh konsumen dan dari perusahaan ke perusahan dengan komputer sebagai perantara traksaksi bisnis.

Masa pandemi sebenarnya memberikan peluang untuk usaha mandiri dengan memanfaatkan Media Sosial dan e-commerce. Dengan kemajuan teknologi saat ini dapat memanfaatkan peranan internet dan perangkat mobile yang dimiliki untuk mengembangkan usaha yang dimiliki secara online sehingga memungkinkan pencapaian pasar yang lebih luas. Hal ini memberikan semangat peneliti untuk memberikan pendampingan terhadap beberapa penjual atau seller dengan berjualan online melalui sosial media maupun beberapa platform seperti Tokopedia, Bukalapak, dan Shopee di desa Pandansari Kecamatan Poncokusumo Malang. Tahap awal peneliti berbagi cerita terkait pembukaan toko online shop di beberapa platform, setelah itu beberapa orang merasa tertarik. Kemudian mereka belajar membuka toko dan produk-produk yang mereka punya, dengan memanfaatkan secara maksimal terhadap sumber daya alam, kapasitas dan keterampilan yang ada di daerah. Tujuannya adalah mengoptimalkan dan menciptakan perekonomian lokal yang lebih baik dan lebih kuat dari sebelumnya. Beberapa produk yang ditawarkan adalah lemon, sari lemon, buah-buahan, sayur mayur, bahkan ada yang menjual kreasi kue-kue beraneka ragam. Berikut gambargambar toko online shop dari beberapa masyarakat pandansari; 


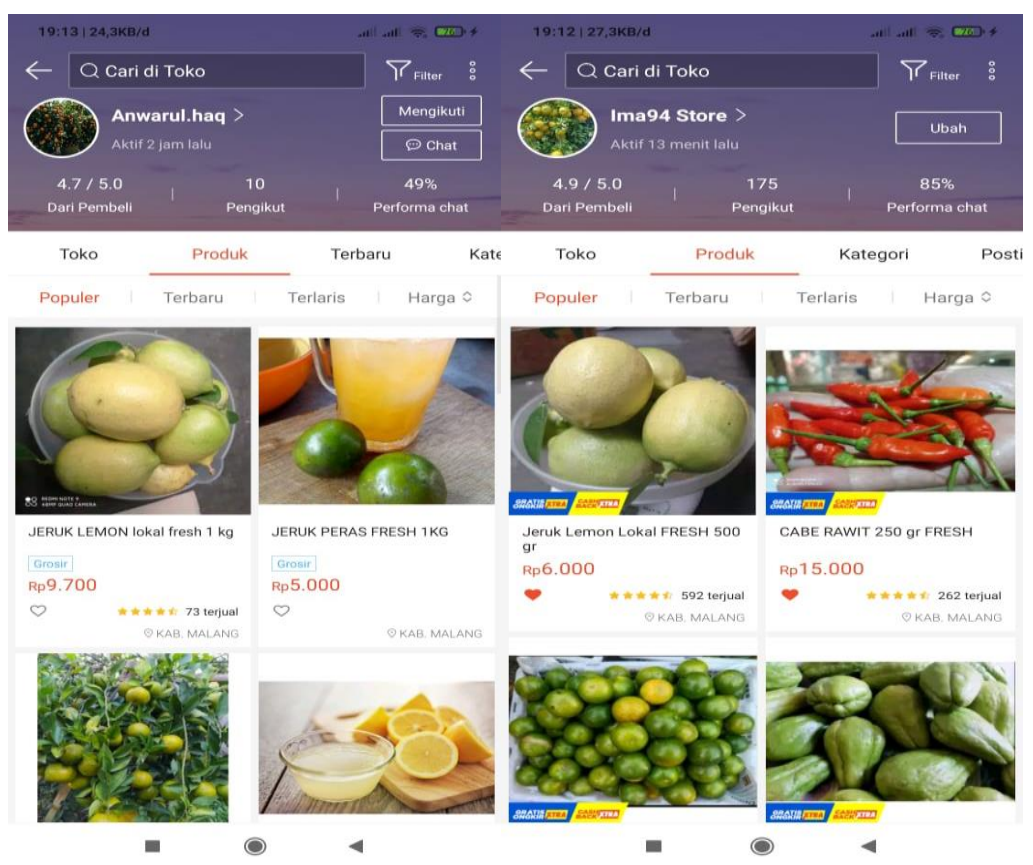

Gambar 3.1

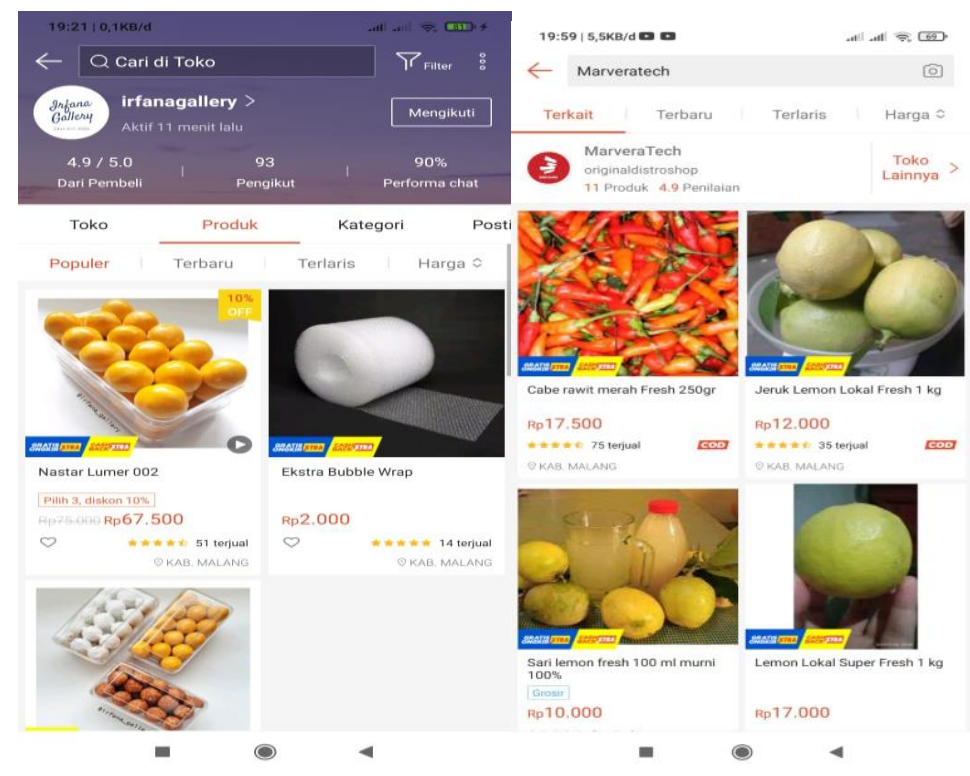

Gambar 3.2

\section{KESIMPULAN DAN SARAN}

\section{Kesimpulan}

Kasus Covid-19 di Indonesia terus meningkat, tercatat per 1 September 2020 sebanyak 177.571 orang positif covid-19, 12.057 orang sembuh, dan 7.505 orang meninggal dunia dan angka ini bisa saja akan terus bertambah. Angka masyarakat yang positive covid19 terus meningkat, padahal pemerintah dan tim medis sendiri sudah melakukan cara 
terbaik sesuai dengan kemampuan dan kondisi Indonesia saat ini. Covid-19 tersebut berdampak pada tiga bidang kehidupan yaitu kesehatan, pendidikan, dan ekonomi. Banyak pelaku bisnis yang gulung tikar, tidak memenuhi target usahanya, dan daya beli masyarakat menurun. Pasca pandemi terdapat beberapa usaha yang melejit di tengah pandemi yaitu, penjuakan masker kain, hand sanitizer, kuliner dengan berbagai kuliner yang unik dan murah, serta jasa kurir yang menyediakan jasa pengiriman barang karena banyak masyarakat yang enggan bepergian dan lebih memilih menggunakan jasa kurir untuk mengirim barang. Masa pandemi sebenarnya memberikan peluang untuk usaha mandiri dengan memanfaatkan Media Sosial dan e-commerce. Dengan kemajuan teknologi saat ini dapat memanfaatkan peranan internet dan perangkat mobile yang dimiliki untuk mengembangkan usaha yang dimiliki secara online sehingga memungkinkan pencapaian pasar yang lebih luas. Adanya pandemic ini, banyak kehilangan pekerjaan yang secara tidak langsung memacu masyarakat untuk menggali kemampuan dan skill diri, sehingga mendorong mereka untuk menciptakan usaha secara online dengan memanfaatkan digital sebagai toko online shop mulai lewat sosial media maupun beberapa platform seperti Tokopedia, Bukalapak, dan Shopee.

\section{Saran}

Peneliti beranggapan bahwa masa pandemic sebenarnya memberikan peluang untuk usaha mandiri dengan memanfaatkan Media Sosial dan e-commerce, banyak kehilangan pekerjaan yang secara tidak langsung memacu masyarakat untuk menggali kemampuan dan skill diri, sehingga mendorong mereka untuk menciptakan usaha secara online dengan memanfaatkan digital sebagai toko online shop mulai lewat sosial media maupun beberapa platform seperti Tokopedia, Bukalapak, dan Shopee. Selain itu toko online shop dapat mengoptimalkan dan menciptakan perekonomian lokal yang lebih baik dan lebih kuat dari sebelumnya. 


\section{DAFTAR ISI}

Rianto, Nur. Penjualan On-line Berbasis Media Social Dalam Perspektif Ekonomi Islam. Ijtihad, Jurnal Wacana Hukum Islam dan Kemanusiaan, 2013. Volume 23, No.1, jurnal diakses pada tanggal 02 Juli 2021.

Muzdalifah, Laily dkk. Pemberdayaan Pelaku UMKM Menuju UMKM Go-Digital Di Era Pandemi Covid 19 Dan Era New Normal Bagi Pelaku UMKM Sidoarjo. Malang: UNMER. 2020.

Edgar, Alvin dkk. Analisa Transaksi Belanja Online Pada Masa Pandemi Covid-19, Surabaya: Institut Tekonologi, Jurnal TEKNOINFO, Vol. 15, 2021, jurnal diakses pada tanggal 30 Juni 2021.

Endriastuti, Annysa dan Putri, Maurisia. Pelatihan Pemasaran, Pemberdayaan Toko Online, dan Pengenalan M-Commerce pada Produk Unggulan Jagung Tortila Di Kecamatan Trucuk Kabupaten Bojonegoro, Universitas Airlangga, Jurnal Pengabdian Masyarakat, Vol. 1 No. 2 Tahun 2018, jurnal diakses pada tanggal 01 Juli 2021.

Zakka, Nizam dan Sofyantoro. Pemberdayaan Ekonomi Kreatif dan UMKM di Masa Pandemi Melalui Digitalisasi, Madiun: Universitas PGRI, Jurnal Pemerintahan, Pembangunan dan Inovasi Daerah, Vol.2 No.1 Juni 2020, jurnal diakses pada tanggal 01 Juli 2021.

Nidaul, Fata dkk, Pemanfaatan Media Sosial dan Ecommerce Sebagai Media Pemasaran dalam Mendukung Peluang Usaha Mandiri Pada Masa Pandemi Covid 19, Junal JSTPM Vol. 1 No.1 Juli 2020, jurnal diakses pada tanggal 30 Juni 2021.

Novia, Putu dkk, Bisnis Kuliner Online, Solusi Usaha di Tengah Pandemi Covid-19, Denpasar: Universitas Mahasaraswati, Prosiding Webinar Nasional Peranan Perempuan/Ibu dalam Pemberdayaan Remaja di Masa Pandemi COVID-19, artikel diakses pada tanggal 01 Juli 2021.

Mihadi, Yananto dkk, Pendampingan Penerapan Sistem Pemasaran Online dan Pelaporan Keuangan Sederhana Pada Sektor Usaha Kecil di Kelurahan Meruya Selatan, Jakarta: Universitas Mercu Buana, Jurnal Abdi Masyarakat, Vol.5 No.1 September 2019, jurnal diakses pada tanggal 01 Juli 2021.

Affan, Richardy dkk. Analisis Transaksi Jual-Beli Online (Peer To Peer)Pada E-Commerce Berdasarkan Hukum Syariah. Journal Of Islamic Economics Lariba (2017). Vol. 3, Universitas Islam Negeri Syarif Hidayatullah. 